\title{
OUR CONTROVERSY WITH VENEZUELA
}

From the days of Bolivar, the liberator, to the time of Castro, the dictator, the United States has maintained an attitude of friendship and protection towards Venezuela. At times we have found ourselves at variance with different governmental administrations of Venezuela over questions involving the rights and property interests of American citizens, which have temporarily threatened our friendly relations, but at no period of Venezuela's national history have the questions assumed so serious a phase as at present. Although we have always heretofore succeeded in adjusting our differences in an amicable manner through the medium of diplomacy to the satisfaction of both nations, yet now there does not appear to be any desire on the part of the Castro Government to arrive at an accommodation.

The Castro Government once before assumed an insolent and defiant attitude towards creditor nations with the result that England, Germany and Italy, sent battleships to blockade the Venezuelan ports. President Castro's Government was speedily brought to its senses, and entered into protocol agreements looking to the arbitration of the claims of foreigners. The tribunals which passed upon these claims, awarded nearly $\$ 7,000,000$ to the claimants. Such a lesson ought to have been sufficient, but it has not proven so, and now we are confronted by another like condition.

There is no sentiment of hostility among the people of Venezuela toward foreign enterprise, and our quarrel is not with them. Our difficulties are caused by the ring of political adventurers which at present controls Venezuela. There is no finer territory for development on the globe than that of Venezuela, and no people more refined and cultivated than the educated Venezuelans. They possess everything requisite to a high place in the family of nations, but they are ruled by the whim and will of an unscrupulous executive and his entourage. This is destructive to Venezuela's national welfare, and any action which would check this misrule would tend to the advancement of civilization.

The time is ripe, and foreign intervention would undoubtedly afford an opportunity for an internal readjustment. Not only would legitimate business enterprises of foreigners be protected 
and encouraged, and enabled to proceed with their proper work of development, but the interests of the Venezuelan people would be subserved. As has been remarked by an eminent member of our Senate Committee on Foreign Relations, "Castro needs a spanking."

The controversy of the United States with Venezuela is largely due to the five claims of American citizens against Venezuela, which for several years past our State Department has endeavored to settle or to have arbitrated. The defiant attitude with which we have been met has sorely tried our patience, and a point has now been reached when our position should be definitely taken and the substantial interests of our citizens in Venezuela properly safeguarded.

At the last session of Congress, the State Department submitted to the Senate, in answer to a resolution by that body, all of the diplomatic correspondence relating to these five claims, of which that of the New York and Bermudez Company is, perhaps, the most widely known, as it has been extensively commented upon by the press from time to time. It was made the subject of a special report to the President, by William J. Calhoun, Special Commissioner, who virtually concludes, that while the Venezuelan Government acted within its rights upon some of the points complained of by the Company, the latter, on the whole, suffered grievous wrongs at the hands of the executive and judicial branches of the Venezuelan Government.

Venezuela has laid great stress upon the conspiracy into which the Company is alleged to have engaged for the purpose of overthrowing the Government, but in the conclusion to his report, the Special Commissioner says: "Many charges and countercharges of combination, conspiracy, fraud and corruption, have been made by both sides to the controversy," and, speaking of the revolutionary suit brought by the Venezuelan Government in the Venezuelan Courts, he says: "So far as I have been able to ascertain, this action is without precedent, and the right to maintain same is at least a debatable question."

This controversy arising out of the alleged revolutionary conspiracy, was not necessarily limited to the jurisdiction of the Venezuelan Courts, and Venezuela would have shown the height of wisdom and the utmost good faith had she availed herself of the opportunity, which was open to her, of proceeding against the Bermudez Company in some court of competent jurisdiction in 
the United States, for the alleged participation in the Matos Rebellion. An action might have been brought in the United States against the Company for damages for any breach of the contract of concession. Venezuela, however, chose to confine herself to her local tribunals, and the Company alleges a denial of justice because of the judgments rendered after procedure, that the State Department describes as a "travesty upon justice."

An issue is raised which is essentially a fit subject for arbitration, and which cannot now be satisfactorily determined justly and without bias in any other manner. If the Bermudez Company has been guilty of wrongs against Venezuela, and if Venezuela has been guilty of wrongs against the Bermudez Company, an international tribunal can and should determine the right or wrong and the measure of damages in the case.

Pending such arbitration, Americans, at least, will give weight to the declaration of the State Department in submitting the Bermudez claim to the Senate. In the introduction to the summary of this claim, the Department says: "The conclusions which follow have been reached only after it has been shown, as it would seem beyond peradventure, that the company's claim is perfect, not only from a legal standpoint, but, more important still, from the standpoint of equity and the broad principles of right and of fair play."

And at the end of the summary of the case the Department adds: "It is submitted that the foregoing pages show that the property rights of the New York and Bermudez Company have been violated in spite of the best efforts of the Company to defend itself; that this result has been accomplished by gross misuse of judicial and executive authority, and that Venezuela should be held responsible therefor. The gravamen of the complaint is that the Company went into Venezuela with a great capital, which it invested there, and as a result of procedure which has been a travesty upon justice, is turned out of its property without a dollar; that its interests were made over to its business rivals, and that its mine, worth millions of dollars, which it has been working for years under valid and undisputed titles, has been wrenched from its possession by the violent hands of the Venezuelan Government under pretexts of legal process; that the irregularity of these proceedings has been brought time and again to the attention of the Venezuelan Government; that that Government, through its Courts and its Executive, has persistently ignored the 
appeals both of the complainant and of this Department in its behalf; and that as a matter of fact, the Venezuelan Government is itself the direct agent through which these wrongs are being perpetrated."

Another of these claims is that of A. F. Jaurett, which arises out of the arbitrary expulsion of $\mathrm{Mr}$. Jaurett from Venezuela on twenty-four hours' notice, given to him on a Sunday morning, the reason assigned being that he was prejudicial to public order. There can be no question as to the sovereign right to expel an alien if his conduct is dangerous to the State, but he must be accorded proper treatment and the right to be heard, as well as a decent interval in which to arrange his affairs. No such consideration was shown Mr. Jaurett, and certainly his claim should be insisted upon as a proper subject for arbitration.

With respect to the claims of the Orinoco Steamship Company and of the United States and Venezuelan Company, it is contended that the contracts of concession owned by these companies and which form the basis of their claims against Venezuela, contain what is commonly known as the Calvo Clause, which it is attempted to construe as confining the question at issue to the local tribunals of Venezuela. The Orinoco Steamship Company r.ad been engaged in a well-organized shipping and trading business on the Orinoco River, with an investment of over $\$ 940,000$, until it was interfered with by the Castro Government. The Company strbmitted its claim to the United States and Venezuelan Claims Commission which sat at Caracas, in 1903, and Venezuela took no exception to its submission, notwithstanding the Calvo Clause in the contract of concession, and thus recognized the jurisdiction of an international tribunal in a case of this character.

When the claim was presented to the Commission, the commissioners were unable to agree upon an award, and it went to the umpire, Dr. Barge, for decision. The umpire adopted the Calvo theory, and also took the technical position that notice of the transfer to the claimant had never been given to Venezuela, and upon this technicality disallowed all claims prior to April I, I902, which constituted practically all of the claims owned by the Company. This was so flagrantly at variance with the terms of the protocol, as Venezuela had specifically agreed to the submission of "all claims owned by citizens of the United States of America against the Republic of Venezuela," that the United 
States has taken the firm position that this claim should be rearbitrated. The amount of the claim presented to the Commission was $\$ 1,401,559.03$, and the umpire awarded only the sum of $\$ 28,224.93$ on some of the minor items running subsequent to April I, I902. The chief item was for the breach of the contract which was prior to that date and was clearly established. The decision is full of peculiarities, eccentricities and technicalities.

To the proposition of the United States, that the claim be reexamined by an impartial and competent international tribunal, the Castro Government has answered that the clecision of the United States and Venezuelan Claims Commission is final, and sets it up as a bar. The umpire dic not adhere to the terms of the protocol, uncler which he was sworn to act, that all claims should be decided "upon a basis of absolute equity, without regard to objections of a technical nature," and upon all the facts in this contention there can be no question of the propriety of our demand that the matter should be the subject of review by an international arbitration.

The claim of the United States and Venezuelan Company, generally known as the Critchfield claim, is a clear case, and the obligations of the American concessionary have been performed in good faith. This contract of concession was granted by President Castro, acting as provisional president, and was covered by a general ratification in the resolution of the Venezuelan Congress, passed February 25, 1902, approving of all "the acts executed by the Citizen-General Cipriano Castro, during the period in which he has exercised the provisional presidency of the Republic." The property affected by this claim is an asphalt mine called Inciarte, and a railway concession to connect the mine with the port. This mine was purchased for $\$ 25,000$ cash, through George W. Critchfield, an American citizen, and with the expenditures required under the contract for the canalization of rivers to render them navigable, the construction and operation of the railroad, the mining and refining plant and clearing of forests, the Company has now expended over $\$ 600,000$.

The concession was granted in I9OI, and provides that neither this enterprise nor the products of its mines can be burdened with any kind of national taxes or contributions except those prescribed by the then existing law relating to mines. Under the then existing law, the Company was only obligated to pay a nominal tax on the area of the mine, amounting to $\$ 30$ per annum. 
Notwithstanding this contract, the Castro Government subsequently enacted a law imposing additional taxation, increasing the tax on the area of the mine, and taxing the gross product of the mine. By executive decree, further taxes were imposed on the exports of asphalt and on the net products of the exploitation of the mine. Besides all this, the Company was forced to pay import dues on certain articles imported for its mine and railroad. The result has been an oppressive burden laid upon the Company in violation of the express provisions of the contract of concession.

The Company has appealed to the State Department, which has taken the position that either the Venezuelan Government should live up to its contract in all respects, or submit the question involved to an impartial arbitral tribunal.

The claim of the Orinoco Corporation shows palpable wrong on the part of the Venezuelan Government. This claim arises out of the tortuous acts of the Government against the corporation and its predecessors, in connection with the famous Fitzgerald concession in the Delta of the Orinoco River.

For twenty-five years this valuable grant has been the source of continuous international dispute. It was unquestionably granted to an American citizen as a political play, to insure American diplomatic intervention in the trouble which Venezuela foresaw would arise with England over the delimitation of the line between Venezuela and British Guiana. In I 895 the territory in which the concession lay was invaded by an armed British force. This called forth the memorable message of President Cleveland, and nearly involved us in war with England. It was the direct cause which led up to the British-Venezuelan Boundary Arbitration in 1899 , by which about one-third of the territory of the concesssion was adjudicated to Great Britain.

Almost from the inception of the Fitzgerald grant, the Venezuelan Government by illegal and inconsistent acts, especially its granting of other contravening concessions, gave constant cause for diplomatic action. The question of the title to the concession was brought before the United States and Venezuelan Claims Commission in 1903, which, by its decision, re-established the Fitzgerald concession, which is now vested in the Orinoco Corporation. In 1906, the Venezuelan Federal Courts held, in a suit brought by one J. Padron-Uztariz, to declare the Fitzgerald contract insubsistent, that a contract which had been properly 
granted could not be annulled by the decree of the Executive. The Orinoco Corporation is thus doubly assured of its rights. But, notwithstanding the decision of the International Tribunal, the Castro Government during the pendency of the PadronUztariz action, made three separate grants in conflict with the rights of the Orinoco Corporation, and even after the highest constitutional court of Venezuela had rendered its decision, made a further grant of property within the Fitzgerald concession.

How can any business enterprise be devoloped in the face of such governmental conduct, interfering with its title and granting away its vested rights?

Those interests which have worked under the Fitzgerald concession, have always conformed to the letter of Venezuelan law and the precepts of International Law ; they have consistently followed a policy of conciliation and have made repeated efforts to arrive at an equitable settlement of their difficulties; they have appealed to the executive, legislative and judicial branches of the Venezuelan Government, yet their rights, guaranteed them by the Venezuelan law and constitution, have been invaded and their property destroyed.

The claimants have submitted their questions to the Venezuelan Courts and have been victorious, only to find that the Venezuelan Executive overrides the decision of the Courts. The Orinoco Corporation has joined with the other claimants in asking that its difficulties with the Castro Government be left again to international arbitration.

The attitude of the Castro Government in these various matters would be amusing, if it were not for the fact that the questions involved are so serious.

In the case of the Orinoco Steamship Company, the technical decision of the umpire is regarded by President Castro as "a finality," as it is eminently satisfactory to him.

In the case of the Orinoco Corporation, President Castro ignores the proceedings of the judicial branch of the Venezuelan Government as well as the decision of the Claims Commission, because they do not suit him.

These two claimants have united with the other three, in asking for the creation of an international commission, which shall determine the rights of each as against Venezuela. But would the arbitration be effective with President Castro still in power? Arbitration has clearly not been effective to materially benefit the 
Orinoco Steamship Company and the Orinoco Corporation, but they certainly show the utmost good faith with Venezuela in their expressed wish to the State Department, that a tribunal be constituted to take cognizance of their claims. The requests of our State Department have at all times been reasonable, and the Castro Government should have promptly acceded, if fairness and good faith exist on its side.

At the Second Hague Conference, delegates from forty-five nations, representing the best thought of the civilized world, were assembled. These delegates were able men, who labored to bring about measures upon which all nations might agree. One of the chief questions discussed was the use of force against nations for the collection of contractual clebts claimed to be due, in favor of citizens or subjects of other nations. It was unanimously agreed, that force should not be employed by one nation against another for the collection of debts of this character, until arbitration had been proposed and carried out and then disregarded, or it had been proposed by one and refused by the other.

The United States has carefully followed the spirit of this conference. In the Orinoco Corporation matter, the arbitration has been disregarded by the Castro Government, and in the other matters we have proposed arbitration, stating sufficient grounds in each case, and the Castro Government has refused. At the present time, diplomatic relations between the two countries have been severed.

Congress should authorize such measures as will assure justice to these five claimants, that is, if necessary, to make use of force in demanding and compelling a fair and impartial arbitration of the questions at issue, and providing for an effective means of enforcing the decisions of the tribunal. Action of this character would be wholesome, and uncloubtedly would be welcomed by the better class of Venezuelans, for it would afford them the opportunity to minimize if not utterly do away with the arbitrary power of the Castro Government, which retards the natural development of their country. Robert C. Morris, D.C.L.

Lecturer on International Arbitration and Procedure, Yale Law School; Counsel for the United States before the Venezuelan Claims Commission. 
"Since this article was written there have been developments in the Venezuelan situation in harmony with the suggestions of the author. First came a display of force by Holland, then an effort to readjust the internal affairs of Venezuela through the assumption of power by Vice-Presiclent Gomez, the deposing of Castro, and the appointment of a new Cabinet, and, finally, the official communication to the United States from the new Government of Venezuela expressing the wish of President Gomez to settle satisfactorily all international questions. Unless disorders occur to change the new administration it only remains to provide a proper method of carrying out effectively the settlement which may be agreed upon, or the enforcement of awards of a Court of Arbitration should it be decided to settle the matters in controversy by such means. At the same time substantial guarantees for future stability in the Venezuelan Government and the protection of the interests of foreigners should be securecl." $-E d$. 